\title{
SLAMF6 Gene
}

National Cancer Institute

\section{Source}

National Cancer Institute. SLAMF6 Gene. NCI Thesaurus. Code C105055.

This gene acts as a coreceptor in the process of natural killer cell activation. 